\title{
Çeşitli Klinik Örneklerden İzole Edilen Staphylococcus aureus Suşlarının Antibiyotik Direnç Oranları
}

\section{Antibiotic Resistance Rates of Staphylococcus aureus Strains Isolated from Various Clinical Samples}

\author{
Hülya Duran*®, Nihan Çeken**๑, Tuğba Kula Atik***® \\ * Dr. İsmail Fehmi Cumalıoğlu Şehir Hastanesi, Mikrobiyoloji Laboratuvarı, Tekirdağ, Türkiye \\ ** Balıkesir Devlet Hastanesi, Mikrobiyoloji Laboratuvarı, Balıkesir, Türkiye \\ *** Balıkesir Üniversitesi Tıp Fakültesi, Tıbbi Mikrobiyoloji Anabilim Dalı, Balıkesir, Türkiye
}

Atıf/Cite as: Duran H, Çeken N, Kula Atik T. Çeşitli klinik örneklerden izole edilen Staphylococcus aureus suşlarının antibiyotik direnç oranları. Turk Mikrobiyol Cemiy Derg. 2021;51(3):233-8.

öz

Alındığı tarih / Received: 05.01.2021 / 05.January. 2020

Kabul tarihi / Accepted: 18.02.2021 / 18.February. 2021

Yayın tarihi / Publication date: 07.09.2021 / 07.September.2021

\section{ORCiD Kayıtları}

H. Duran 0000-0002-4838-0730

N. Çeken 0000-0003-1877-7320

T. Kula Atik 0000-0002-2433-1977

tkulaatik@gmail.com
Amaç: Staphylococcus aureus hem toplum hem de hastane kaynaklı enfeksiyonlara neden olabilen önemli bir patojendir. Metisilin dirençli izolatların varlığı tedavi seçeneklerini kısıtlamaktadır. Bu çalışmanın amacı, hastanemizde ayaktan ve yatan hastalardan izole edilen S. aureus suşlarında antibiyotik direnç oranlarını saptamaktır.

Yöntem: 2016-2019 yılları arasında çeşitli klinik örnekler retrospektif olarak değerlendirilmiş ve S. aureus suşları çalış̧maya dâhil edilmiştir. Bakteri tanımlaması ve antibiyotik duyarlıık testleri konvansiyonel yöntemler ve otomatize sistemler kullanılarak yapılmıştır.

Bulgular: Yaptığımız bu çalışmada, 595 S. aureus suşu değerlendirilmiştir. Çalışmaya dâhil edilen suşlar en sık kan ve yara örneklerinden izole edilmiştir. Yüz yetmiş iki izolat (\%28.9) metisilin dirençli S.aureus (MRSA) olarak tanımlanmıștr. Eritromisin, tetrasiklin, klindamisin, gentamisin, siprofloksasin ve trimetoprim-sülfametoksazole karşı \%16.8 oranında veya altında direnç saptanmıştr. Bu antimikrobiyallere karşı MRSA'larda metisilin duyarlı S.aureus (MSSA) suşlarına kıyasla yüksek direnç oranları gözlenmiştir. Vankomisin, teikoplanin ve linezolide karşı direnç saptanmazken daptomisine $\% 0.7$ oranında direnç bulunmuştur.

Sonuç: Antibiyotik direnci günümüzün en önemli sağlık sorunlarından biridir. Gerek metisilin gerekse diğer antibiyotiklere direnç S.aureus enfeksiyonlarında tedavi başarısını düşürmektedir. Bu nedenle antibiyotik direnç sürveyanslarının düzenli olarak izlenmesi oldukça önemlidir.

Anahtar kelimeler: Staphylococcus aureus, MRSA, antibiyotik direnci

ABSTRACT

Objective: Staphylococcus aureus is an important pathogen that can cause both community and hospital-acquired infections. The presence of methicillin resistant isolates limits treatment options. The aim of this study was to determine the antibiotic resistance rates in S. aureus strains isolated from outpatients and inpatients in our hospital.

Method: Various clinical specimens were evaluated retrospectively between 2016-2019 and $S$. aureus strains were included in the study. Bacterial identification and antibiotic susceptibility tests were performed using conventional methods and automated systems.

Results: In our study, $595 \mathrm{~S}$. aureus strains were assessed. The strains included in the study were most frequently isolated from blood and wound samples. One hundred and seventy- two isolates (28.9\%) were identified as methicillin resistant $S$. aureus (MRSA). The resistance rates to erythromycin, tetracycline, clindamycin, gentamicin, ciprofloxacin and trimethoprim-sulfamethoxazole were $16.8 \%$ or below. High resistance rates were observed in MRSA against these antimicrobials compared to methicillin-susceptible S. aureus (MSSA) strains. Resistance was not found against vancomycin, teicoplanin and linezolid, whereas resistance to daptomycin was $0.7 \%$.

Conclusion: Antibiotic resistance is one of the most important health problems of today. Resistance to both methicillin and other antibiotics decreases the success rates of treatment in S. aureus infections. Therefore, it is very important to regularly monitor antibiotic resistance surveillance.

Keywords: Staphylococcus aureus, MRSA, antibiotic resistance 


\section{Giriş}

Staphylococcus aureus hem toplum kaynaklı enfeksiyonlara hem de hastane enfeksiyonlarına sıklıkla neden olabilen, solunum yolu, idrar yolu, ciltyumuşak doku ve kan yolu enfeksiyonları gibi çok çeşitli klinik tablolar ile seyredebilen önemli bir bakteriyel insan patojenidir ${ }^{(1-4)}$. S. aureus'un çevrede yaygın olarak bulunması yanında çoğu sağılıkı bireyin deri ve mukoza zarları gibi normal florasında da bulunması potansiyel olarak ciddi enfeksiyon kaynağ olmasını kolaylaştırmaktadır ${ }^{(1,2,4)}$.

Staphylococcus aureus enfeksiyonlarının tedavisi, enfeksiyonun türüne ve enfeksiyona neden olan suşun antibiyotik duyarlılı̆̆ına bağlı olarak değişiklikler göstermektedir ${ }^{(1)}$. MRSA (metisiline dirençli Staphylococcus aureus) suşları seftarolin ve seftobiprol gibi anti-MRSA etkili yeni sefalosporinler dışında diğer $\beta$-laktam grubu antibiyotiklere dirençli olmakla birlikte, makrolidler, linkozamidler, kinolonlar ve aminoglikozidlere de direnç gösterebilmektedir ${ }^{(4,5)}$. Bu direnç gelişimi nedeniyle MRSA enfeksiyonlarının tedavisinde vankomisin, teikoplanin, linezolid, daptomisin gibi antimikrobiyallerin kullanımı zorunlu duruma gelmektedir ${ }^{(4,6)}$. MRSA gibi çoklu antibiyotiğe dirençli suşların ortaya çıkması tedavi yönetimini zorlaştırmanın yanında, morbidite, mortalite ve hasta maliyeti yükünü de önemli derecede arttırmaktadır ${ }^{(3,5,6)}$. Akılcı antibiyotik kullanım politikalarının yerleştirilebilmesi için antibiyotik direnç sürveyanslarının düzenli olarak izlenmesi ampirik tedaviye yol gösterilmesinde oldukça önemlidir(4-6).

Çalışmamızda, çeşitli klinik örneklerden izole edilen S. aureus suşlarının antimikrobiyal direnç oranlarını saptamak ve ampirik tedavi kararına yol göstermek amaçlanmıştır.

\section{GEREÇ ve YÖNTEM}

Çalışmamızın etik kurul onayı Balıkesir Üniversitesi Klinik Araştırmalar Etik Kurulu'ndan alınmıştır (19.08.2020tarih, 2020/135 karar No.). Çalışmamızda, 2016-2019 yılları arasında hastanemiz mikrobiyoloji laboratuvarına gönderilen endotrakeal aspirat (ETA), kan, idrar, yara, balgam ve kateter ucu örnekleri gibi çeşitli klinik örnekler retrospektif olarak incelenerek, S. aureus üremesi saptanan örnekler çalışmaya dâhil edilmiştir.

Tüm örnekler kanlı agar ve eosin methylene blue (EMB) agara ekim yapılarak $37^{\circ} \mathrm{C}^{\prime}$ de $24-48$ saat inkübe edilmiştir. İzole edilen suşlar konvansiyonel yöntemler (koloni morfolojisi, gram boyama, katalaz ve koagülaz testi) ve BD Phoenix 100 otomatize identifikasyon sistemi (BD Phoenix System, Beckton Dickinson, $A B D$ ) ile tanımlanmıştır. İzolatların in-vitro antibiyotik duyarlılıkları European Committee on Antimicrobial Susceptibility Testing (EUCAST) $)^{(7)}$ kriterleri temel alınarak Phoenix TM 100 otomatize tanımlama ve antibiyotik duyarlılık test sistemi (Beckton, Dickinson and Company, ABD) kullanılarak saptanmıştır. Metisilin direncinin belirlenmesi için sefoksitin MiK değeri (>4 mg/L) kullanılmıştır.

\section{BULGULAR}

Çalışmamızda, 595 S. aureus suşu izole edilmiş ve değerlendirmeye alınmıştır. S. aureus suşlarının \%52.9'u kan, \%28.1'i yara, \%10.3'ü ETA, \% 3.4'ü idrar, \%3'ü balgam ve \%2.3'ü kateter ucu örneklerinden belirlenmiştir. Suşların izole edildiği ETA, kan ve kateter ucu örneklerinin tamamının yatan hastalara; yara, balgam ve idrar örneklerinin \%55.1'inin ayak$\tan , \% 44.9^{\prime}$ unun ise yatan hastalara ait olduğu görülmüştür.

İzole edilen suşların \%28.9'unda (172 izolat) metisilin direnci saptanmış ve MRSA olarak sınıflandııımıştır. Metisilin direnci 2016 yılında \%19, 2017 yılında \%37.7, 2018 yılında \%23.7 ve 2019 yılında \%33 olarak saptanmıştır. MRSA izole edilen örneklerin \%12.2'sinin ayaktan hastalara (tamamı yara örneği), $\% 87.8^{\prime}$ inin yatan hastalara ait olduğu izlenmiştir.

Değerlendirmeye dâhil edilen $S$. aureus suşlarında ( $n=595)$ en yüksek direnç oranı \%92.6 ile penisilin için gözlenmiştir (Tablo 1). Vankomisin, teikoplanin ve linezolide karşı direnç saptanmazken, daptomisine \%0.7 oranında direnç bulunmuştur. MRSA suşlarında MSSA (metisiline duyarlı Staphylococcus aureus) tür- 
Tablo 1. İzole edilen Staphylococcus aureus suşlarının antibiyotik direnç oranları.

\begin{tabular}{|c|c|c|c|c|c|c|}
\hline \multirow[b]{2}{*}{ Antibiyotik } & \multicolumn{2}{|c|}{ MRSA } & \multicolumn{2}{|c|}{ MSSA } & \multicolumn{2}{|c|}{ Toplam } \\
\hline & $(n=172)$ & $\%$ & $(n=423)$ & $\%$ & $(n=595)$ & $\%$ \\
\hline Penisilin & 172 & 100 & 379 & 89.6 & 551 & 92.6 \\
\hline Gentamisin & 55 & 32 & 36 & 8.5 & 91 & 15.3 \\
\hline Klindamisin & 60 & 34.9 & 28 & 6.6 & 88 & 14.8 \\
\hline Eritromisin & 66 & 38.4 & 34 & 8 & 100 & 16.8 \\
\hline Tetrasiklin & 58 & 33.7 & 0 & 0 & 58 & 9.7 \\
\hline TMP-SXT & 18 & 10.5 & 12 & 2.8 & 30 & 5 \\
\hline Siprofloksasin & 49 & 28.5 & 27 & 6.4 & 76 & 12.8 \\
\hline Vankomisin & 0 & 0 & 0 & 0 & 0 & 0 \\
\hline Teikoplanin & 0 & 0 & 0 & 0 & 0 & 0 \\
\hline Linezolid & 0 & 0 & 0 & 0 & 0 & 0 \\
\hline Daptomisin & 4 & 2.3 & 0 & 0 & 4 & 0.7 \\
\hline
\end{tabular}

TMP-SXT: Trimetoprim-sülfametoksazol

MRSA: Metisilin dirençli Staphylococcus aureus; MSSA: Metisilin duyarlı Staphylococcus aureus

Tablo 2. İzole edilen Staphylococcus aureus suşlarının klinik örneklere göre antibiyotik direnç oranları.

\begin{tabular}{|c|c|c|c|c|c|c|}
\hline Antibiyotik & $\begin{array}{c}\text { Kan } \\
\mathrm{n}=315\end{array}$ & $\begin{array}{c}\text { Yara } \\
n=167\end{array}$ & $\begin{array}{c}\text { ETA } \\
n=61\end{array}$ & $\begin{array}{l}\text { İdrar } \\
n=20\end{array}$ & $\begin{array}{c}\text { Balgam } \\
n=18\end{array}$ & $\begin{array}{c}\text { Kateter ucu } \\
n=14\end{array}$ \\
\hline Penisilin & 98.4 & 85 & 82 & 85 & 100 & 100 \\
\hline Gentamisin & 14.3 & 14.4 & 18 & 40 & 11.1 & 7.1 \\
\hline Klindamisin & 16.5 & 12 & 13.1 & 10 & 11.1 & 28.6 \\
\hline Eritromisin & 18.7 & 11.4 & 16.4 & 25 & 11.1 & 35.7 \\
\hline Tetrasiklin & 11.4 & 3.6 & 16.4 & 10 & 11.1 & 14.3 \\
\hline TMP-SXT & 5.1 & 4.8 & 3.3 & 0 & 5.6 & 21.4 \\
\hline Siprofloksasin & 14 & 8.4 & 14.8 & 15 & 16.7 & 21.4 \\
\hline Vankomisin & 0 & 0 & 0 & 0 & 0 & 0 \\
\hline Teikoplanin & 0 & 0 & 0 & 0 & 0 & 0 \\
\hline Linezolid & 0 & 0 & 0 & 0 & 0 & 0 \\
\hline Daptomisin & 0 & 1.2 & 1.6 & 0 & 0 & 7.1 \\
\hline MRSA & 34.6 & 19.2 & 32.8 & 20 & 16.7 & 28.6 \\
\hline
\end{tabular}

TMP-SXT: Trimetoprim-sülfametoksazol

MRSA: Metisilin dirençli Staphylococcus aureus; ETA: Endotrakeal aspirat

lerine göre tüm antibiyotiklere karşı daha yüksek direnç saptanmıştır (Tablo 1). Klinik örnekler değerlendirildiğinde antibiyotik direnç oranlarının genel olarak birbirine yakın değerlerde seyrettiği ve tüm örneklerde en etkisiz antibiyotiğin penisilin olduğu görülmüştür. Ayrıca MRSA oranının kan ve ETA örneklerinde daha yüksek olduğu gözlenmiştir (Tablo 2).

\section{TARTIŞMA}

Staphylococcus aureus, toplum ve hastane kaynaklı enfeksiyonların önemli etkenlerinden biridir. Başta deri ve yumuşak doku enfeksiyonları olmak üzere bakteriyemi de dâhil birçok lokal ve sistemik hastalığa neden olmaktadır ${ }^{(8,9)}$. Bakterinin sıklıkla izole edildiği klinik örnekler literatürde farklı yelpazede bildirilmektedir ${ }^{(6,8,10)}$. Tanrıverdi ve ark. ${ }^{(6)}$ en sık yara örneklerinde, ikinci sıklıkta balgam örneklerinde; Arıcı ve ark. ${ }^{(8)}$ en sık ETA örneklerinde, ikinci sıklıkta yara örneklerinde, Barış ve ark. ${ }^{(10)}$ ise en sık solunum, ikinci sıklıkta kan örneklerinde izole etmişlerdir. Yaptığımız çalışmada, S. aureus suşlarının yarısından fazlasının (\%52.9) kan örneklerinden, yaklaşık \%30'unun da yara örneklerinden izole edildiği görülmüştür.

Staphylococcus aureus enfeksiyonlarının tedavisinde ilk başlarda sülfonamid grubu ilaçlar ile penisilin $\mathrm{G}$ kullanılmış fakat penisilin G'ye kısa sürede direnç gelişmiştir $^{(11)}$. Çalışmamızda da penisilin direnci yüksek oranda (\%92.6) saptanmıştır. Metisilinin tedavide kullanımı ile $S$. aureus enfeksiyonlarının tedavisinde başarı sağlanmış fakat 1961 yılında metisilin dirençli suşlar ortaya çıkmıştır ${ }^{(11,12)}$. Dünyada ve ülkemizde 
yapılan çeşitli çalışmalarda MRSA sıklığına baktığımızda; dünyada \%0.9-74(13), ülkemizde ise \%12.2$71.7^{(14)}$ gibi çok geniş bir aralıkta bildirilmektedir. Çalışmamızda, metisilin direnci \%28.9 oranında, çalışmalarla uyumlu bulunmuştur. Çalışmamızın bir kısıtlıı̆̆ı olarak metisilin direnci için doğrulama testleri yapılamamış, otomatize identifikasyon sisteminden alınan sonuçlara göre olası oranlar bildirilmiştir. Klinik örnekler bazında bildirilen MRSA oranlarına baktığımızda, yara örneklerinde Turhanoğlu ve ark. ${ }^{(15)}$ \%35.8, Savcl ve ark. ${ }^{(16)} \% 9$; kan örneklerinde Kula Atik ve ark. ${ }^{(5)} \% 41$, Nazik ve ark. ${ }^{(11)} \% 48.1$; idrar örneklerinde Arıcı ve ark. ${ }^{(8)} \% 15$, Özel ve ark. ${ }^{(17)} \% 33.3$; ETA örneklerinde Tartar ve ark. ${ }^{(18)} \% 100$; balgam örneklerinde Orak ${ }^{(19)} \% 100$, solunum yolu örneklerinde (ETA ve balgam) Koçak ve ark. ${ }^{(20)} \% 28.6$ olarak belirlemişlerdir. Yaptığımız çalışma ile karşılaştırırsak birbirine hem çok yakın hem de çok farklı oranların olduğunu görüyoruz. Bu durum bize antibiyotik direnç oranlarının merkezler arası değişiklik gösterebileceğini kanıtlamaktadır. Ayrıca çalışmamızda MRSA oranlarının yıllar içinde değişkenlik gösterdiği, 2016 yılına kıyasla 2019 yılında arttığı saptanmıştır. Bu nedenle her merkezin kendi verisini oluşturması kadar düzenli olarak takip etmesi ve güncellemesi de önemlidir.

MRSA suşları tedavide önemli olan $\beta$-laktam grubu antibiyotiklere direnç göstermesinin yanında makrolidler, linkozamidler, kinolonlar ve aminoglikozidler gibi birçok farklı grup antimikrobiyale de direnç geliştirebilmektedir ${ }^{(5)}$. Çalışmaya dâhil edilen $S$. aureus suşlarında ( $n=595)$ penisilin hariç diğer antibiyotiklere karşı \%16.8 ve altında, düşük direnç oranları saptanmıştır. Fakat gentamisin, klindamisin, eritromisin, tetrasiklin, Trimetoprim-sülfametoksazol (TMP-SXT) ve siprofloksasine karşı MRSA suşlarında saptanan direnç oranları MSSA'larda saptanana göre çok daha yüksek bulunmuştur. Tanrıverdi ve ark. ${ }^{(6)}$ 2018-2019 yıllarında çeşitli klinik örneklerden izole ettikleri $S$. aureus suşlarını değerlendirdikleri çalışmada, MRSA ve MSSA'da sırasıyla eritromisine \%45.1-\%15, klindamisine $\% 43.5-\% 10.6$, tetrasikline $\% 38.2-\% 6$, gentamisine \%33.3-\%11.3, siprofloksasine \%37.5-\%8.2 ve TMP-SXT'e \%14.6-\%1.3 oranında direnç saptamışlardır. Ayrıca çalışmamıza benzer şekilde MRSA suşlarında \%100'e yakın penisilin direnci saptarken MSSA'da bu oranı \%80'lerde bulmuşlardır. Şen ve ark. ${ }^{(21)} 2010$ 2015 yılları arasında ayaktan ve yatan hastaları değerlendirdikleri çalışmada direnç oranlarını MRSA'da eritromisine \%57.4, klindamisine \%45.1, tetrasikline $\% 54.3$, gentamisine $\% 50$, siprofloksasine \%44.4 ve TMP-SXT'ye \%20.9; MSSA suşlarında ise eritromisine $\% 10$, klindamisine $\% 1.4$, tetrasikline $\% 7.3$, gentamisine $\% 5.8$, siprofloksasine $\% 4.1$ ve TMP-SXT'ye \%1.5 olarak saptamışlardır. Gerek yaptığımı çalışma, gerekse diğer iki çalışma değerlendiğinde literatür ile uyumlu olarak MRSA suşlarında MSSA'lara göre direnç oranlarının daha yüksek olduğu görülmüştür.

MRSA suşlarında görülen çoklu ilaç direnci, S. aureus enfeksiyonlarının tedavisinde alternatif antibiyotiklerin kullanılmasına neden olmuştur ${ }^{(22)}$. Vankomisin, teikoplanin, daptomisin, tigesiklin ve linezolid MRSA tedavisinde kullanılan önemli ajanlardır(23-25). Amerika'da SENTRY Antimikrobiyal Sürveyans Programı'nda, kan örneklerinden izole edilen MRSA suşlarında teikoplanine \%1.2, vankomisin, linezolid, daptomisin ve tigesikline ise $\% 1^{\prime}$ in altında direnç belirlenmiştir ${ }^{(26)}$. Shariati ve ark. ${ }^{(27)}$ 'nı yaptığı çok merkezli çalışmada ise, MRSA suşlarında daptomisin, linezolid ve tigesikline \%0.1 oranında direnç bulunmuştur. Ülkemizden yapılan çalışmalara baktığımızda, birçok merkezin bu antimikrobiyallere karşı direnç bildirmediğini i $(5,6,8,17,19,28)$ görüyoruz. Bununla beraber, Şen ve ark. ${ }^{(21)}$ daptomisine $\% 0.2$, linezolide \%0.4; Nazik ve ark. ${ }^{(11)}$ daptomisine \%2.6, tigesikline \%2.6 ve teikoplanine \%7.8; Davarcı ve ark. (29) yalnızca daptomisine \%4.2 oranında direnç bildirmişlerdir. Çalışmamızda, tüm $S$. aureus suşlarında daptomisine \%0.7 oranında direnç saptanmış, vankomisin, teikoplanin ve linezolid direnci gözlenmemiştir. Hastanemizde, MRSA kaynaklı enfeksiyonların tedavisinde daptomisin kullanımının yaygın olmasının bu duruma neden olabileceğini düşünüyoruz.

Özetle S. aureus, gerek ayaktan gerekse yatan hastalarda önemli bir enfeksiyon etkenidir ve metisilin direnci tedavi seçeneklerini oldukça kısıtlamaktadır. Çalışmamızdan hareketle, hastanemiz için S. aureus enfeksiyonlarında rutin tedavide sıklıkla 
tercih edilen eritromisin, klindamisin, tetrasiklin, TMP-SXT gibi antibiyotiklerin ampirik olarak başlanmasının uygun olacağı, antibiyogram sonucuyla da tedavi rejiminin yeniden düzenlenmesinin tedavi başarısını arttıracağı açıktır.

Etik Kurul Onayı: Çalışma, Balıkesir Üniversitesi Tıp Fakültesi Klinik Araştırmalar Etik Kurulu, 19.08.2020 ve 2020-135 numaralı kararı ile onaylanmıştır.

Çıkar Çatışması: Yazarlar bu makale ile ilgili herhangi bir çıkar çatışması bildirmemişlerdir.

Ethics Committee Approval: The study protocol was approved by the Balıkesir University, Medical Faculty, Clinical Research Ethics Committee (08.19.20202020/135).

Conflict of Interest: No conflict of interest was declared by the authors.

\section{KAYNAKLAR}

1. Tong SY, Davis JS, Eichenberger E, Holland TL, Fowler VG. Staphylococcus aureus infections: epidemiology, pathophysiology, clinical manifestations, and management. Clin Microbiol Rev. 2015;28(3):603-61. https://doi.org/10.1128/CMR.00134-14

2. Fitzgerald JR. Evolution of Staphylococcus aureus during human colonization and infection. Infect Genet Evol. 2014; 21: 542-7.

https://doi.org/10.1016/j.meegid.2013.04.020

3. Guo Y, Song G, Sun M, Wang J, Wang Y. Prevalence and therapies of antibiotic-resistance in Staphylococcus aureus. Front Cell Infect Microbiol. 2020; 10: 107. https://doi.org/10.3389/fcimb.2020.00107

4. Şanlı K. Hastane kökenli ve toplum kaynaklı Staphylococcus aureus suşlarının çeşitli antimikrobiyallere duyarlılıkları. IKSSTD. 2020;12(2): 188-93. https://doi.org/10.5222/iksstd.2020.64326

5. Kula Atik T, Uzun B. Kan kültürlerinden izole edilen Staphylococcus aureus suşlarının metisiline ve diğer antimikrobiyal ajanlara direnç durumlarının değerlendirilmesi. Klimik Derg. 2020;33(2):132-6. https://doi.org/10.5152/kd.2020.28

6. Tanrıverdi ES, Duman Y, Tekerekoğlu MS. Bir üniversite hastanesi'nde 2018-2019 yıllarında izole edilen Staphylococcus aureus izolatlarının incelenmesi. Fırat Tip Derg. 2020;25(4):184-8.

7. EUCAST. Breakpoint tables for interpretation of MICS and zone diameters, Version 10.0.2020. The European
Committee on Antimicrobial Susceptibility Testing. 2020.

8. Arıcı N, Aksaray S. Klinik örneklerden izole edilen Staphylococcus aureus suşlarının metisilin direncinin belirlenmesive antibiyotik duyarlılıklarının araştırılması. ANKEM Derg. 2019;33(2):70-6.

https://doi.org/10.5222/ankem.2019.1922

9. Okalın şş, Aksakal A. Kronik süpüratif otitis medialı hastalardan Staphylococcus aureus suşlarının izolasyonu ve antibiyotik duyarlılıklarının araştırılması. Turk Mikrobiyol Cemiy Derg. 2020;50(3):148-55. https://doi.org/10.5222/TMCD.2020.148

10. Barış A, Bulut ME, Öncül A, Bayraktar B. Yoğun bakım ünitelerinde yatan hastalara ait klinik izolatların tür dağılımı ve antibiyotik duyarlılıkları. J Turk Soc Intensive Care. 2017;15(1):21-7. https://doi.org/10.4274/tybdd.55707

11. Nazik S, Cingöz E, Şahin AR, Güler S. Kan kültürlerinden izole edilen Staphylococcus aureus suşlarında metisilin direncinin yıllara göre değişimi. Kocaeli Med J. 2018;7(1):32-6. https://doi.org/10.5505/ktd.2018.94824

12. Orhan Z, KayışA, Akyol I, Aral M. Farklı klinikörneklerden izole edilen Staphylococcus aureus izolatlarında metisilin, yüksek düzey mupirosin ve fusidik asit direncinin fenotipik ve genotipik olarak araştırılması. Sakarya Tıp Dergisi. 2017;7(3):131-7. https://doi.org/10.31832/smj.325570

13. Hassoun A, Linden PK, Friedman B. Incidence, prevalence, and management of MRSA bacteremia across patient populations-a review of recent developments in MRSA management and treatment. Crit Care. 2017;21(1):211-21. https://doi.org/10.1186/s13054-017-1801-3

14. Şay Coşkun US. Kan kültürlerinde üreyen mikroorganizmalar ve antibiyotik duyarlılıkları. ANKEM Derg. 2018;32(2):45-52. https://doi.org/10.5222/ankem.2018.045

15. Turhanoğlu NM, Koyuncu E, Bayındır Bilman F. Yara kültürlerinden izole edilen mikroorganizmalar ve antibiyotik dirençleri, 2010-2015. Turk Hij Den Biyol Derg, 2018;75(2):183-94. https://doi.org/10.5505/TurkHijyen.2018.56338

16. Savcı Ü, Alıç T, Güreser AS, Özkan AT. Ortopedik cerrahi sonrası yara enfeksiyonları: mikroorganizmaların dağılımları ve direnç durumları. Ortadogu Med J. 2018;10(4):492-97. https://doi.org/10.21601/ortadogutipdergisi.399737

17. Özel Y, Büyükzengin KB, Yavuz MT. Klinik örneklerden izole edilen metisiline dirençli ve duyarlı Staphylococcus aureus suşlarının antibiyotik direnç profilinin araştırılması. ANKEM Derg. 2017;31(2):41-7. https://doi.org/10.5222/ankem.2017.041 
18. Sağmak Tartar A, Özer AB, Ulu R, Akbulut A. Endotrakeal aspirat örneklerinden izole edilen bakteriler ve antibiyotik duyarlııkları: bir yıllık retrospektif analiz. Klimik Derg. 2018;31(1):56-60.

https://doi.org/10.5152/kd.2018.14

19. Orak F. Mardin Devlet Hastanesi'nde 2011-2013 yılları arasında metisiline dirençli stafilokoklarda direnç profilleri. Turk Hij Den Biyol Derg. 2015;72(3):191-8. https://doi.org/

20. Koçak AA, Yayla B, Güçlü AÜ ve ark. Adana'da bir üniversite hastanesinde izole edilen solunum yolu patojenleri ve antibiyotik direnç profillerinin değerlendirilmesi. Turk Mikrobiyol Cemiy Derg. 2019;49(4):226-32.

https://doi.org/10.5222/TMCD.2019.226

21. Şen P, Demirdal T, Özdemir R ve ark. Stafilokoklarda antimikrobiyal direnç: 6 yıllık değerlendirme. Medeniyet Med J. 2017;32(4):205-11. https://doi.org/10.5222/MMJ.2017.205

22. Emre A, Seyman D, Türker $M$ ve ark. Toplum kökenli metisiline dirençli Staphylococcus aureus etkenli deri ve yumuşak doku enfeksiyonu olguları. Klimik Derg. 2020;33(2):180-4.

https://doi.org/10.5152/kd.2020.38

23. Küçükateş E. Gültekin N. Yoğun bakım ünitelerinde yatan hastalardan elde edilen metisilin dirençli stafilokok suşlarında tigesiklin etkinliğinin araştırılması. Med Bull Haseki. 2017;55(1):52-5. https://doi.org/10.4274/haseki.3190

24. Öcal Demir S, Atay G, Kangallı Ö. ve ark. Dirençli gram pozitif enfeksiyon tedavisinde vankomisin ve linezolid kombinasyonu: olgu sunumu. Çocuk Dergisi. 2018;18(2):93-6.

https://doi.org/10.5222/j.child.2018.58224

25. Taşbakan MI, Uysal S, Kömür S, ve ark. Osteomiyeliti olmayan diyabetik ayak enfeksiyonlarında daptomisin tedavisi:çok merkezli çalışma. Flora. 2017;22(4):148-52. https://doi.org/10.5578/flora.66267

26. Diekema DJ, Hsueh P, Mendes RE, et al. The microbiology of bloodstream infection: 20-year trends from the SENTRY antimicrobial surveillance program. Antimicrob Agents Chemother. 2019;63(7): e00355-19. https://doi.org/10.1128/AAC.00355-19

27. Shariati A, Dadashi $M$, Chegini $Z$, et al. The global prevalence of daptomycin, tigecycline, quinupristin/ dalfopristin, and linezolid-resistant Staphylococcus aureus and coagulase-negative staphylococci strains: a systematic review and metaanalysis. Antimicrob Resist Infect Control. 2020;56(9):56. https://doi.org/10.1186/s13756-020-00714-9

28. Bayındır Bilman F, Çiçek B. Kan kültürlerinden izole edilmiş metisiline dirençli Staphylococcus aureus ve koagülaz negatif stafilokok suşlarının seftarolin, linezolid ve vankomisin in vitro duyarlıığının değerlendirilmesi. Turk Mikrobiyol Cemiy Derg. 2019;49(1):35-40. https://doi.org/10.5222/TMCD.2019.035

29. Davarcı I, Koçoğlu ME, Barlas N, Samastı M. Yara kültürlerinden izole edilen bakterilerin antimikrobiyal duyarlılıkları: üç yıllık değerlendirme. ANKEM Derg. 2018;32(2):53-61. https://doi.org/10.5222/ankem.2018.053 